\title{
IMPROVED PERFORMANCE OF PHOTOVOLTAIC BASED EMBEDDED DUAL POWER SOURCE SL-QUASI Z SOURCE INVERTER FOR IM DRIVE
}

\author{
${ }^{1}$ S. Priyadharsini, ${ }^{2}$ T. S. Balaji Damodhar, ${ }^{3}$ C. Kannan, ${ }^{4}$ L. Ganesh Babu \\ 1,3 Associate Professor, Department of Electrical and Electronics Engineering, \\ Arunai Engineering College, Tiruvannamalai, Tamil Nadu, India, \\ ${ }^{2}$ Professor, Department of Electrical and Electronics Engineering, \\ Ranippettai Engineering College, Walajah, Tamil Nadu, India,
}

${ }^{4}$ Assistant Professor, Mechatronics Engineering, Tishk International University, Erbil, KRG, Iraq.

\begin{abstract}
This paper presents the performance of $P V$-based embedded dual power source of SL quasi $Z$ source inverter. The $S L$ quasi $Z$ source inverter with an embedded PV source and a dual power source (DPS) is injected into the system. The DPS helps the system to operate at an equilibrium state and stabilizes the entire system during PV power fluctuations. The design of the proposed system is carried out in MATLAB/Simulink environment. The control strategy with the PI controller is adopted. ESLQ Z source inverter with voltage boost method is employed with basic SPWM methodology will be suitable for IM drive applications. The system has the merit of a low inrush current that will protect and increase the life of switching devices. Finally, the study and simulation setup is validated by proving their good operating features. The proposed work is trustworthy that minimizes the total distortion factor, start-up inrush current with improved performance.
\end{abstract}

KEYWORDS: Photo voltaic (PV), embedded dual power SL quasi $Z$ source inverter, Induction motor drive (IM), PI controller.

\section{INTRODUCTION}

The decreasing of fossil fuels and increasing environmental pollution leads the researcher to concentrate on ever-green technology such as renewable energy. In such cases, the researcher has to adopt a novel and robust system to ensure the system's capability and performance metrics. Meanwhile, a lot of parameters influence the complexity of the entire system that will affect the performance. The proposed work will eliminate the complexity and increases the performance of the embedded dual power SL quasi Z source inverter with the simple modulation technique, rapid boost voltage, and robust structure. Impedance source inverters can be utilized for both buck and boost functions in a unique system.

Turning ON the same phase leg can be made simultaneously is possible in this type of setup and not available in conventional voltage source inverter (VSI) and current source inverter (CSI) [1]. Control strategy for quasi z source inverter with battery and PV system employs a modified SVM technique to minimize the harmonics content in the output voltage [2]. Proposed PS-PWAM for PV QZS network with MLI with a reduced number of switches leads to reduce the power loss in [3]. 
A small-signal dynamic model for QZSI is proposed with the combination of battery bank and SVM control strategy to achieve the low inductor current and higher efficiency [4]. The voltage-fed quasi z source inverter topology is presented in [5] is suitable for light and heavy loads that are implanted with a DSP processor. It eliminates the problems of abnormal work state in light loads. Voltage stress, inrush current, and common ground problems are avoided in [6]. For low power applications, switched boost inverter (SBI)is replaced by a $Z$ source inverter that reduces the LC pairs [7]. To overcome the drawback in conventional $Z$ source inverter, a new high voltage boost impedance source inverter i.e. switched coupled inductor Quasi $Z$ Source inverter has been proposed with the integration of switched capacitor and switched inductor [8]. Double frequency power mismatch will affect the dc input and ac output, this can be avoided with the help of the capacitance reduction control strategy is proposed [9]. Quasi Z Source inverter in boost mode and grid-tie current controller with plug-in repetitive control is developed in [10]. The QSLZSI is the combination of traditional ZSI and CHB circuits that reduces the count of the components and achieves high boost factors [11]. A new control strategy to suppress the resonance on the impedance networks is proposed in [12]

The proposed work focuses on an SL quasi Z source inverter with an embedded PV source and a dual power source. This topology employs the dual battery power source to gain the voltage level during fluctuations and to maintain an equilibrium operating state. The simple SPWM technique is used to reduce the complexity in the existing traditional SL Quasi Z Source inverter. The PV fluctuations by PV panels are eliminated in this system and it is suitable for IM drive applications.

\section{PROPOSED EMBEDDED DUAL POWER SOURCE SL-QUASI Z SOURCE INVERTER}

Figure 1 shows the traditional single-phase QZSI for PV power conversion. The QZSI has $h$ an impedance network consisting of a couple of inductor $\mathrm{L}_{1} \& \mathrm{~L}_{2}$, a couple of capacitor $\mathrm{C}_{1} \& \mathrm{C}_{2}$, and a diode $\mathrm{D}_{1}$ in the photovoltaic section with a dc link.

Where, $\mathrm{C}_{\mathrm{p}}$ is the $\mathrm{PV}$ panel capacitor, $\mathrm{V}_{\mathrm{O}}$ is the ac output voltage and $\mathrm{L}_{\mathrm{f}}$ is the filter inductor. Mean while, $\mathrm{V}_{\mathrm{g}}$ and $\mathrm{i}_{\mathrm{s}}$ denotes grid voltage and grid-tie current.

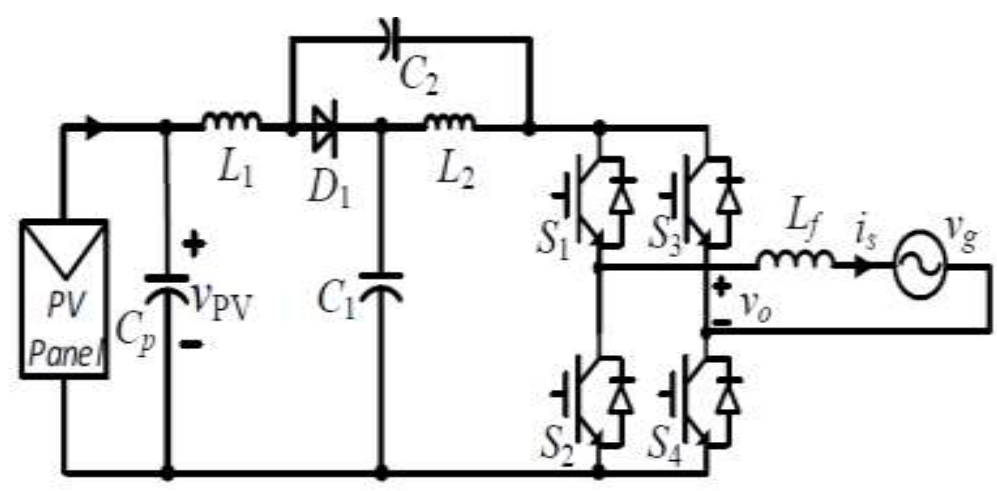

Figure 1. Traditional SL quasi Z source inverter

To avoid PV fluctuations, one or dual dc sources can be connected to an impedance network will make a smoother input current flow and avoids fluctuations. This topology can boost the voltage gain. Figure 2 shows the SL Quasi Z Source inverter with an embedded dual power source for IM drives consisting of battery $V_{D C 1}$ and $\mathrm{V}_{\mathrm{DC} 2}$ are connected in series to the diode $\mathrm{D}_{3}$. The scope of this proposed configuration has to overcome continuous fluctuation input current and also suppress the start-up inrush current caused by the leakage inductance. It can be absorbed by the capacitor $\mathrm{C}_{1}$ and recycled without creating any voltage spike in the target. 


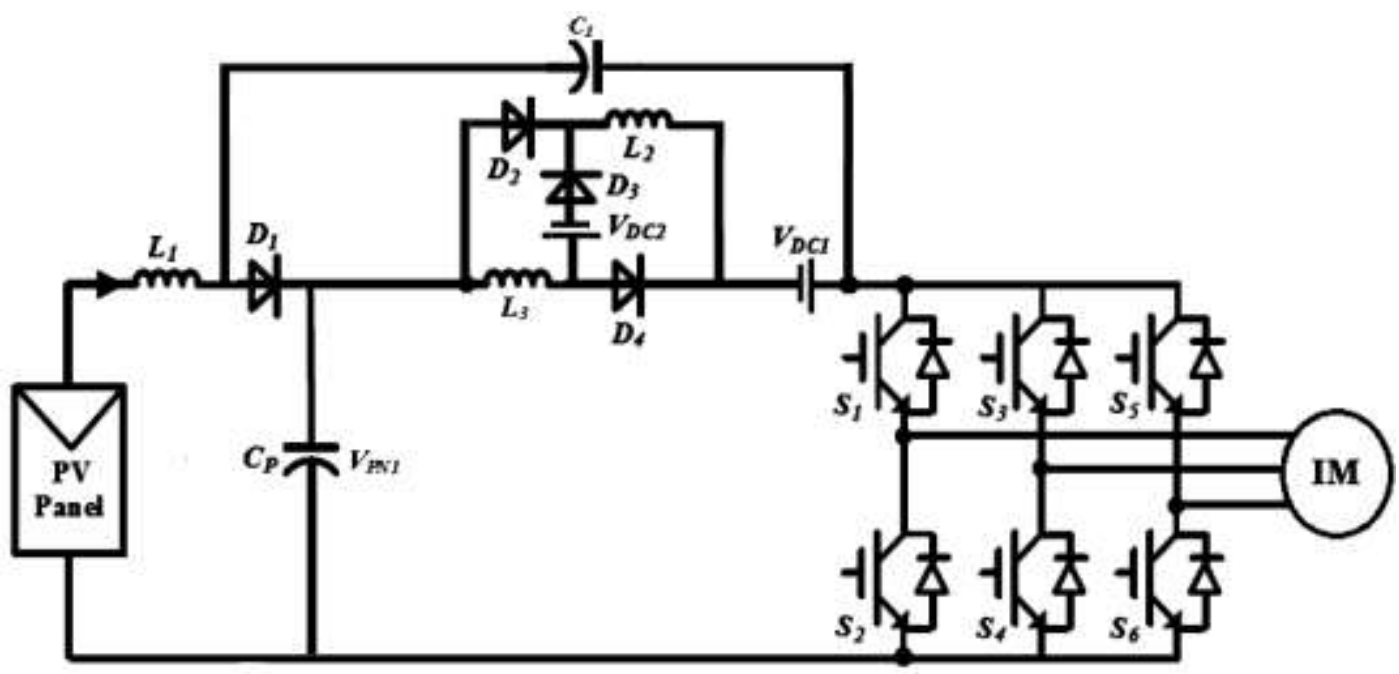

Figure 2: Proposed SL quasi Z source inverter with embedded dual power source for IM drives

Figure 3(a) shows the equivalent circuit in the shoot-through state of the proposed inverter and figure 3(b) shows the equivalent circuit in the non-shoot through state. Both equivalent circuits, 3 (a) and (b) add two capacitors, three inductors, and a dual voltage source.

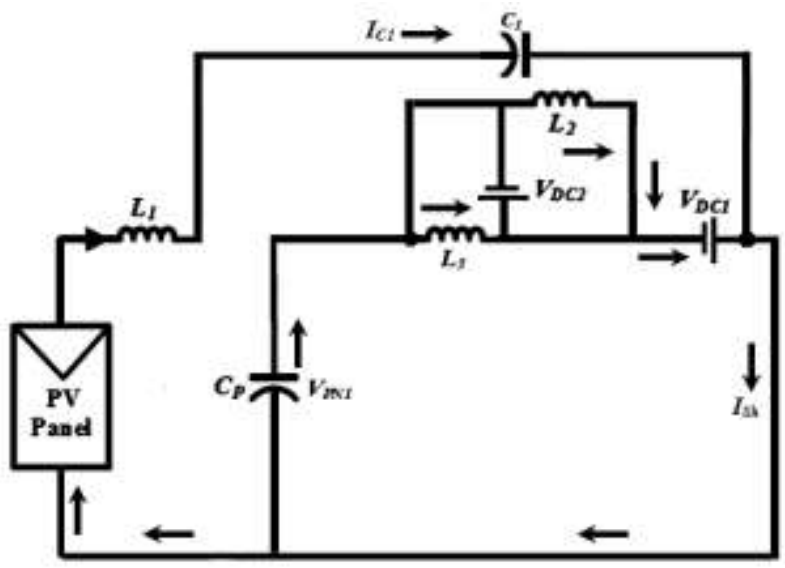

(a)

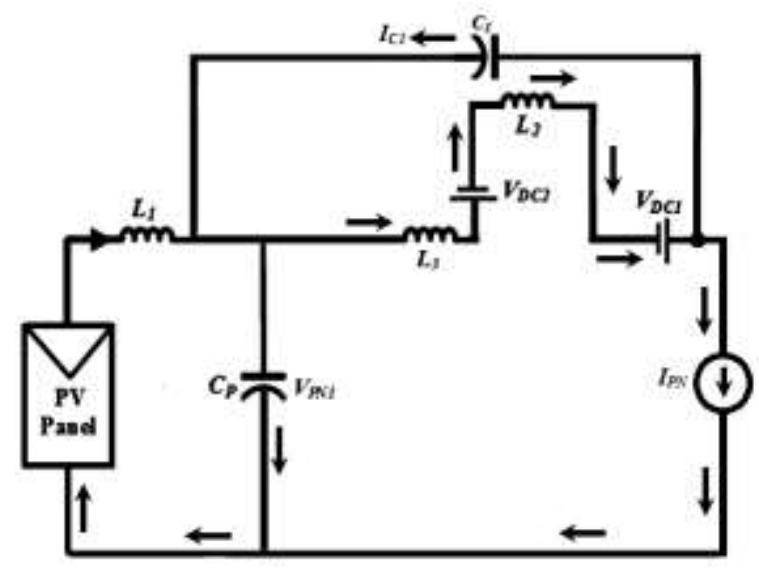

(b)

Figure 3: a) Equivalent circuit in shoot-through state. b) Equivalent circuit in non-shoot through state

This topology is built with a battery and PI controller to have closed-loop operations. The PI controller has robust system performance and reduced fluctuations.

The output voltage $\mathrm{V} 0=\mathrm{V} 0 \sin \omega t$, where $\omega$ is the amplitude and fundamental frequency of ESLQZSI output voltage. During the SPWM period, the dc-link peak voltage VDC $=$ VPV. Hence the voltage fluctuations are eliminated. The modulation index $\mathrm{M}$, angular position $\theta$, shoot-through duty cycle $\mathrm{D}(\mathrm{t})$, and the peak voltage Vdc of the ESLQZSI can be derived and as follows,

$$
\begin{aligned}
& M_{a}=\frac{V_{0}}{V_{p v}} \\
& \theta=\sin \frac{1}{M}
\end{aligned}
$$


$D_{t}(\omega t)=\frac{1-|M \sin (\omega t)|}{1-2|M \sin (\omega t)|}, V_{D C}=\frac{1}{1-2 D_{t}(\omega t)} V_{p v}$

\section{PROPOSED CONTROL STRATEGY OF SPWM WITH PI CONTROLLER}

Figure 4 shows the control strategy of the proposed ESLQZSI with the SPWM technique for a single leg along with an MPPT controller to utilize the full harvested power from the PV panel. The following control objectives are implemented in the embedded dual power SLQZSI. 1. Adaptation of MPPT algorithm. 2. Constant dual power source to avoid PV power fluctuations and, 3. Battery handling system. The PI regulator is implemented to verify the proposed topology. The harvested PV voltage and its reference $V_{P V}$ from MPPT algorithm, and current $\mathrm{I}_{\mathrm{PV}}$ are obtained from the controller to form the phase angle. Feedback of induction motor torque TM is given to the PLL. The dual power source with closed-loop control will achieve the required shoot-through duty ratio to handle the dual battery system to operate in real-time. To achieve the equilibrium condition with fast response, the feed-forward shoot-through duty ratio is given as

$D=\frac{V_{b}}{\left(V_{p v}+2 V_{b}\right)}$

Where $\mathrm{V}_{\mathrm{pv}}$ is the reference output voltage obtained from MPPT, the dual battery power is derived as,

$$
2 P_{b}=P_{\text {out }}-P_{p v}
$$

Where $\mathrm{P}_{\text {out }}$ is the grid injected power to eliminate power fluctuations

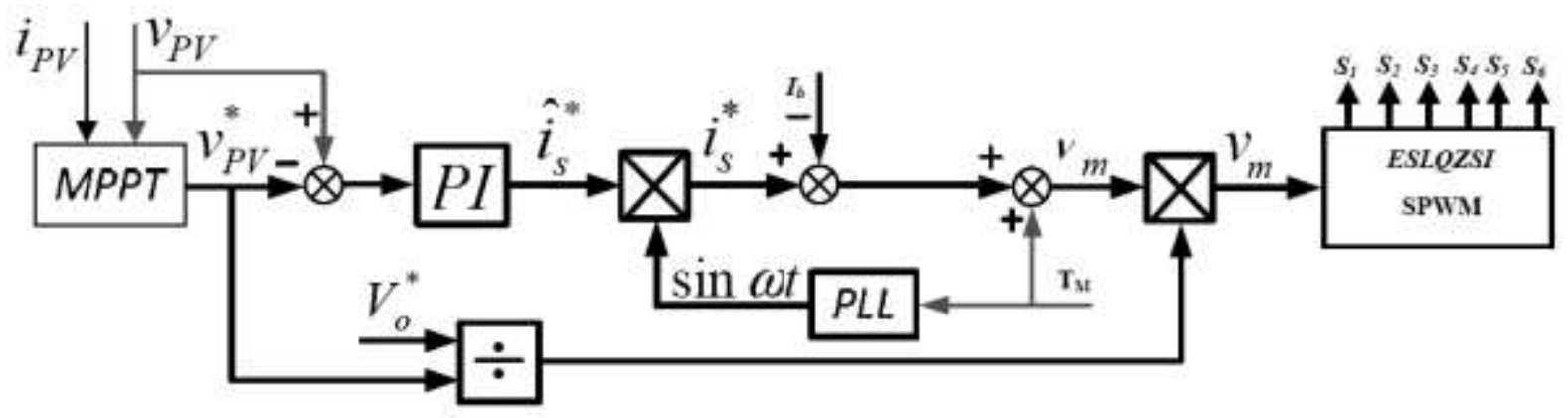

Figure 4. Control strategy of SPWM modulated single leg ESLQZSI for IM drives

The dual power source open loop transfer function is given as,

$D_{\text {ual }}(s)=\frac{i_{b}(s)}{d_{s}(s)}$

Closed loop transfer function is given by,

$D_{\text {ual }}(s)=\frac{d(s)}{i_{b}^{*}(s)}$

From battery power reference, we can get the dual power source reference.

The PI controller coefficient is given by

$P=\frac{1}{V_{P v}}$ 


\section{SIMULATIONS AND EXPERIMENTAL VERIFICATION}

To validate the proposed system, the simulation is carried out in MATLAB/Simulink environment for ESLQZSI with a PI control strategy. Figure 5 presents the harvested output PV voltage of 150volts and is fed to MPPT with PI controller. Figure 6 describes the PV current characteristics and varies with the illumination level of light rays. Figure 7 shows the three-phase voltage waveform of the ESLQZSI fed IM drive without any fluctuation in voltage. Figure 8 gives the output current waveform. Figure 9 demonstrates the IM speed characteristics and rated speed of 1500RPM is achieved. Figure 10 gives information about the torque characteristics. Figure 11 shows THD values at the fundamental frequency of $50 \mathrm{~Hz}$, with a voltage level of 234.4 , and achieves the total harmonics distortion of $1.60 \%$. These results prove that the system is operating in stable conditions.

Table 1 shows the parameter used for the simulation and experimental

\begin{tabular}{|c|c|c|}
\hline Sl. No. & Parameters & Values \\
\hline 1 & Open circuit voltage of PV system & $150 \mathrm{~V}$ \\
\hline 2 & Short circuit current & $8.7 \mathrm{~A}$ \\
\hline 3 & Maximum power voltage & $175 \mathrm{~V}$ \\
\hline 4 & Maximum power current & $7.94 \mathrm{~A}$ \\
\hline 5 & Inductor & $5 \mathrm{Henry}$ \\
\hline 6 & Capacitor & $2800 \mu \mathrm{F}$ \\
\hline 7 & MOSFET & $25 \mathrm{~N} 120$ \\
\hline 8 & Control strategy & PI controller \\
\hline
\end{tabular}

Table 2 PV panel specifications

\begin{tabular}{|c|l|c|}
\hline S.No & \multicolumn{1}{|c|}{ Specification } & Value \\
\hline 1 & Maximum Power (Pmax) & $300 \mathrm{Watts}$ \\
\hline 2 & MPP voltage & $32.0 \mathrm{~V}$ \\
\hline 3 & Open circuit voltage (Voc) & $39.8 \mathrm{~V}$ \\
\hline 4 & MPP current & $9.40 \mathrm{Amp}$ \\
\hline 5 & Short circuit current & $9.98 \mathrm{Amp}$ \\
\hline
\end{tabular}

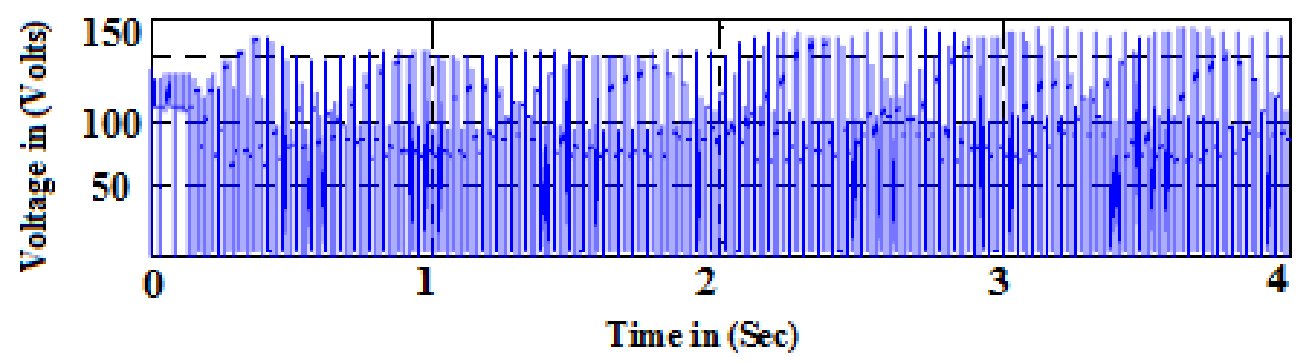

Figure 5: Harvested PV voltage with fluctuation

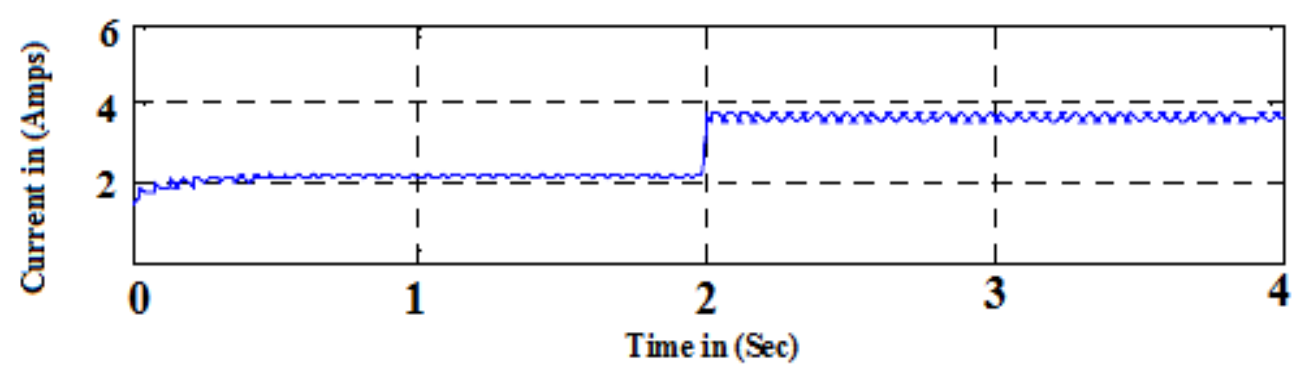

Figure 6: Harvested PV current with fluctuation 


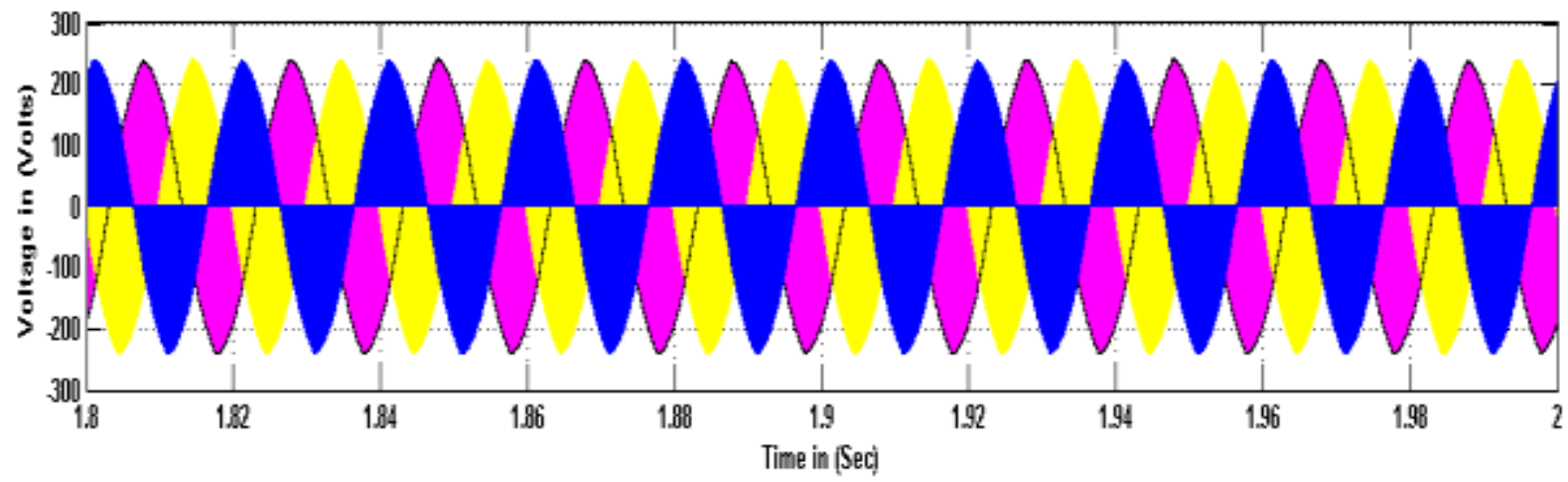

Figure 7: Three phase voltage waveform of ESLQZSI without fluctuation

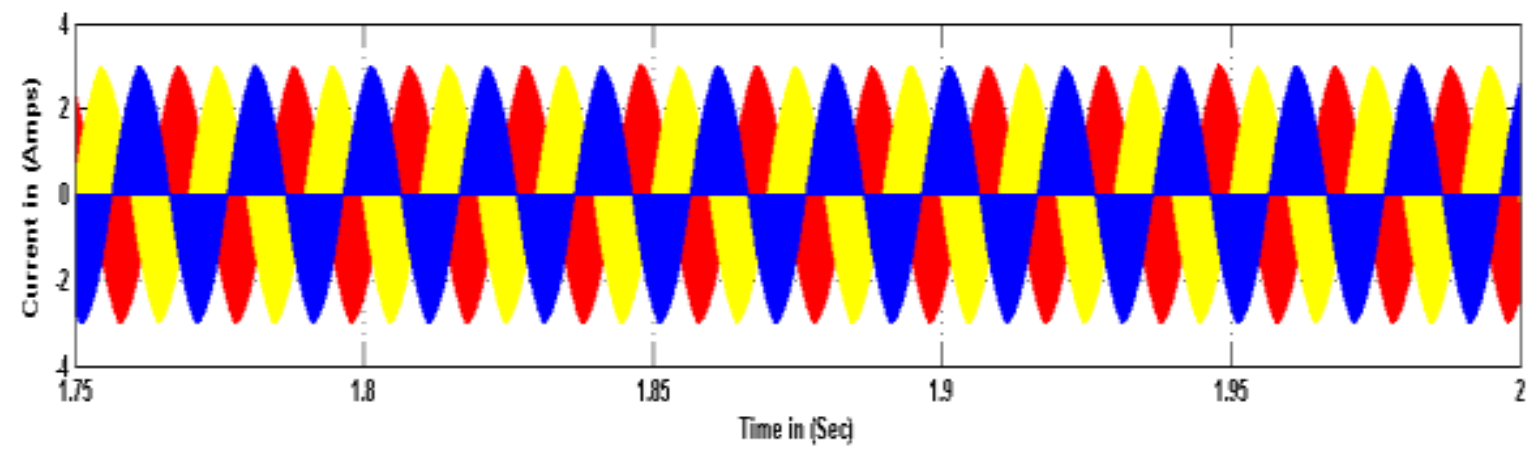

Figure 8: Three phase current waveform of ESLQZSI without fluctuation

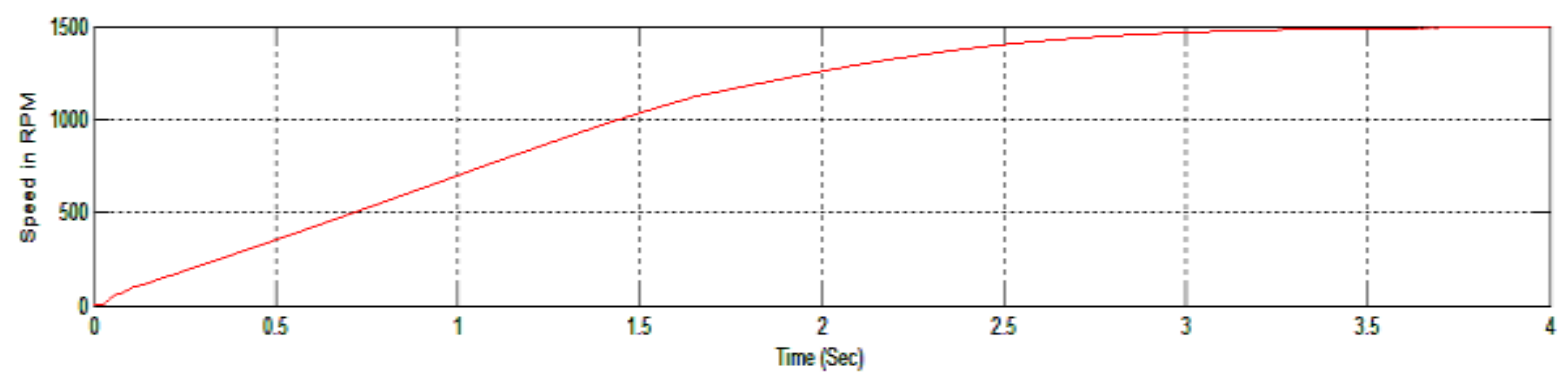

Figure 9: Induction motor speed characteristics

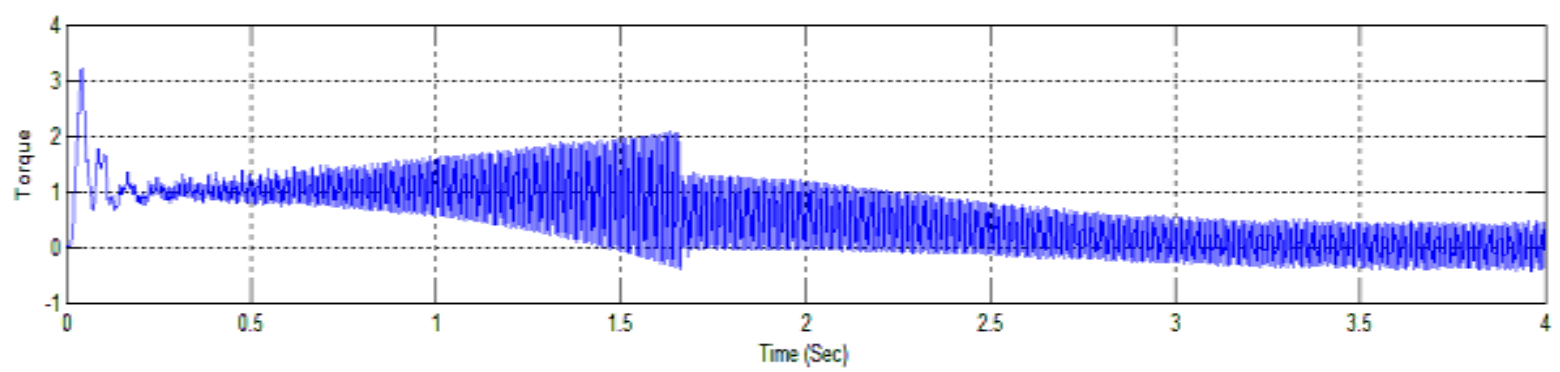

Figure 10: Induction motor torque characteristics 


\section{EPRA International Journal of Research and Development (IJRD)}

Volume: 6 | Issue: 6 | June 2021

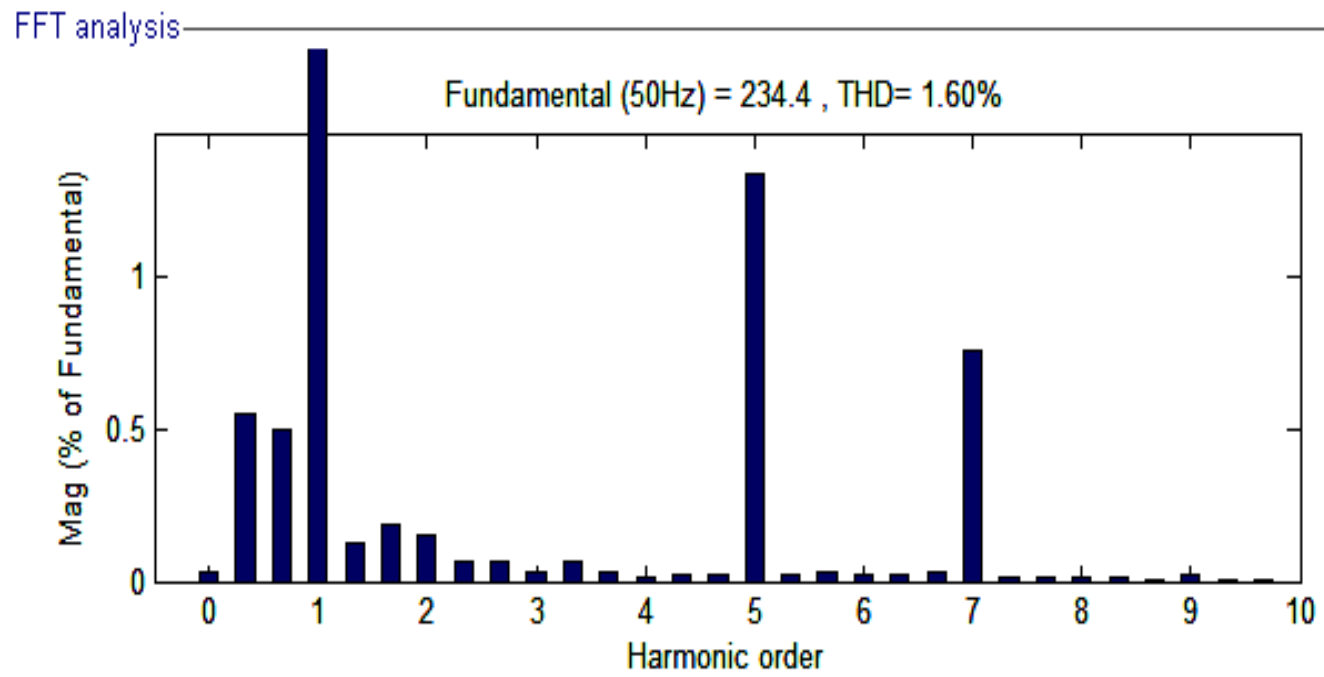

\section{CONCLUSIONS}

Figure 11: Total harmonic distortion

The proposed work concludes that the system is operating in a stable state and the voltage fluctuations from the PV source are overcome with the help of an embedded SL Quasi Z Source inverter with a dual power source. The proposed PI controller achieves high voltage gain during the shoot-through intervals and has low capacitor stress with less inrush current in the PV system. Since the basic SPWM is implemented, the complexity of the system is reduced and has robustness for the proposed topology. A fluctuation input of voltage 100 volts - 150 volts is applied to MPPT and the DPS of 30 volts each is injected. A constant output voltage of 234 volts is obtained without any fluctuations. Apart from this, the THD is much reduced to $1.64 \%$ and the system yields better efficiency. The proposed topology is gently suitable for induction motor drives.

\section{REFERENCES}

1. Fang Zheng Peng “Z-source inverter” IEEE Transactions on Industry Applications. Volume: 39, Issue: 2 Page(s): 504 - 510, Mar/Apr 2003.

2. Yushan Liu, Baoming Ge, Haitham Abu-Rub, Fang Zheng Peng "Control System Design of Battery-Assisted Quasi-Z-Source Inverter for Grid-Tie Photovoltaic Power Generation” IEEE Transactions on Sustainable Energy . Volume: 4, Issue: 4, Oct. 2013.

3. Yushan Liu, Baoming Ge, Haitham Abu-Rub,Fang Peng "Phase-shifted pulse-width-amplitude modulation for quasi-Z-source cascade multilevel inverter-based photovoltaic power system" IET Power Electronics. Volume: 7 , Issue: 6, June 2014.

4. Yushan Liul, Baoming Ge, Haitham Abu-Rub, Fang Zheng Peng "Modelling and controller design of quasi-Zsource inverter with battery-based photovoltaic power system" IET Power Electronics Volume: 7, Issue: 7, July 2014.

5. V Maheswari, V Nandagopal, C Kannan (2014), "Performance Metric of Z Source CHB Multilevel Inverter FED IM for Selective Harmonic Elimination and THD Reduction” Circuits and Systems, Vol 7. No. 11, pp 3794-3806.

6. $\quad$ Xu Peng Fang, Xu Guang Wang, Zhi Qiao Chen "A Single-Phase AC Power Supply Based on Modified Quasi-ZSource Inverter" IEEE Transactions on Applied Superconductivity. Volume: 24, Issue: 5, Oct. 2014.

7. Liqiang Yang, Dongyuan Qiu, Bo Zhang, Guidong Zhang "High-performance quasi-Z-source inverter with low capacitor voltage stress and small inductance" IET Power Electronics Volume: 8, Issue: 6, 62015.

8. Minh-Khai Nguyen, Tuan-Vu Le, Sung-Jun Park,Young-Cheol Lim "A Class of Quasi-Switched Boost Inverters" IEEE Transactions on Industrial Electronics. Volume: 62, Issue: 3, March 2015.

9. C Kannan, NK Mohanty and R Selvarasu, (2017) "A New topology for cascaded H-bridge multilevel inverter with PI and Fuzzy control”, Energy Procedia, Vol.117, pp.917-926.

10. Hafiz Furqan Ahmed, Honnyong Cha, Su-Han Kim, Heung-Geun Kim "Switched-Coupled-Inductor Quasi-ZSource Inverter” IEEE Transactions on Power Electronics. Volume: 31, Issue: 2, Feb. 2016.

11. Balaji Damodhar, TS \& Senthil Kumar, A 2016, 'Implementation of FPGA Based Hybrid Power Generator for PV and Wind Grid Applications', Circuits and Systems, Vol. 7, No.13 pp. 4280-4290.

12. Yan Zhou, Hongbo Li, Hui Li "A Single-Phase PV Quasi-Z-Source Inverter with Reduced Capacitance Using Modified Modulation and Double-Frequency Ripple Suppression Control" IEEE Transactions on Power Electronics. Volume: 31, Issue: 3, March 2016

13. Yushan Liu, Haitham Abu-Rub, and Baoming Ge "Hybrid Pulsewidth Modulated Single-Phase Quasi-Z-Source Grid-Tie Photovoltaic Power System” IEEE Transactions on Industrial Informatics Volume: 12, Issue: 2, April 2016. 
14. $C$ Kannan and C K Kishore (2014), "A comparison of three phase 27 level inverter scheme under no load and multiple load conditions" Bulletin of Electrical Engineering and Informatics, Vol .3, No. 4, pp 245-250.

15. Hailong Liu, Yuyao He, Mingyang ZhangLiu "Quasi-switched-inductor Z-source inverter" Power Electronics and Motion Control Conference (IPEMC-ECCE Asia). 2016 IEEE 8th International conference) 22-26 May 2016.

16. Kannan Chandrasekaran, Nalin Kant Mohanty, Ashwin Kumar Sahoo (2020), "Performance Analysis Of Modular Vs Non Modular Multilevel Inverter", International Conference on Renewable Energy Integration into Smart Grids: A Multidisciplinary Approach to Technology Modelling and Simulation (ICREISG), IEEE, pp.61-67.

17. Thierry Kayiranga, Hongbo Li, Xinchun Lin, Yanjun Shi, Hui Li "Abnormal Operation State Analysis and Control of Asymmetric Impedance Network-Based Quasi-Z-Source PV Inverter (AIN-qZSI)” IEEE Transactions on Power Electronics. Volume: 31, Issue: 11, Nov. 2016.

18. Xiaoquan Zhu, Bo Zhang, DongyuanQiu 2018, 'Enhanced boost quasi-Z-source inverters with active switchedinductor boost network', IET Power Electronics, vol. 11, issue 11, pp. 1774 - 1787.

19. Kannan Chandrasekaran, Nalin Kant Mohanty (2020), "A Flexible Rung Ladder Structured Multilevel Inverter" Tehničkivjesnik, Vol. 27, No. 4, pp 1044-1049.

20. Anh-Vu Ho, Anh-Tuan Huynh, Tae-Won Chun. 2019, "Switched-Capacitor Embedded Quasi-Z-Source Inverters with Advanced Boosting Capability" 2019 IEEE International Conference on Industrial Technology (ICIT).

21. Mehran Sabahi ; Ebrahim Babaei; Taher Ahmadzadeh; Pouya Kolahian; Hadi Tarzamni. 2019. "An Extended Quasi-switched Z-Source Inverter” 2019 10th International Power Electronics, Drive Systems and Technologies Conference (PEDSTC).

22. Rehan Majeed; Aamir Hussain Chughtai, 2019, "Multi-cell Schemes for Active-Switched-Capacitor and ActiveSwitched-Capacitor/Switched-Inductor Quasi Z-Source Inverters" IEEE Journal of Emerging and Selected Topics in Power Electronics.pp.1-1. 